\title{
KARAWITAN BALI DALAM PERSPEKTIF RASA
}

\author{
I Wayan Suweca \\ Jurusan Pedalangan, Fakultas Seni Pertunjukan, \\ Institut Seni Indonesia Denpasar, Indonesia
}

\begin{abstract}
This article is written in order to make a deeply understanding about the concept of Balinese traditional music, especially which related with the sense of musical. The aim of this article is to observe some theories which can be used by the composer in creating songs with sense and different variations of musical. With detail observation of many kind elements that has the possibility to influence and take a part in conveying sense. The method used is the compotation of the composer from some decade. With the priority of the critical science of the study as the main problem in the method used, and hopefully the resume can be used in fixing the study tools about Balinese traditional music. By the understanding of the musical sense as one part of the concept in creating the scientific Balinese traditional music, will open the nest generation ways in thinking to act and create something regularly.
\end{abstract}

Keywords: Karawitan Bali, gong kebyar and rasa.

Seni musik, termasuk juga seni karawitan Bali merupakan sumber penikmatan artistik yang menurut fitrahnya dicerna oleh indra manusia yaitu telinga. Unsur artistik yang menjadi salah satu kreteria utama dalam penyajian sebuah musik mengandung makna yang cukup penting, karena pada akhirnya penikmat karya musik tidak cukup hanya untuk pemuasan indera telinga saja. Penikmat yang lebih mendalam bahkan terjadi kemudian, berlanjut hingga menyentuh apa yang sering kita sebut dengan rasa. Sensitivitas rasa bahkan cenderung lebih mendominasi penikmatan karya musik, karena dengan sentuhan rasa semua unsur menjadi sangat berperan dan perluasan penikmat secara holistik terjadi pada kesemua indra manusia. Rasa dalam hal ini diartikan sebagai gejolak emosional yang muncul akibat sentuhan, dan faktor inilah pada akhirnya menentukan bagaimana tanggapan seseorang terhadap sajian karya musik tersebut. Setelah gejolak emosional terjadi muncul kesan dan kesan inilah menimbulkan tanggapan berupa apresiasi, kritik, pujian, saran, penilaian dan sebagainya. 
Memang harus disadari musik adalah karya seni yang konon paling bersifat abstrak, namun sifat abstrak itu bukanlah diartikan musik itu bisa digarap bebas melainkan ia juga ditata berdasarkan aturan-aturan yang telah dimiliki untuk memenuhi unsur rasa sebagai penikmatan terakhir. Kecermatan untuk meramu unsur-unsur yang ada inilah menyebabkan karya musik mampu memenuhi sifat artistik dalam arti yang sesungguhnya. Dari keragaman cara meramu dan mengolah unsur-unsurnya baik secara musikal maupun ekstra-musikal, dapat memberikan sentuhan rasa yang berbedabeda.

Dalam dunia karawitan Bali kita sering mendengar ungkapan adanya musik yang enak dan ada musik yang janggal. Dalam fugsinya sebagai pendukung suasana baik, yang digunakan dalam iringan seni pertunjukan, protokoler, maupun media ekspresi rasa, seringkali terjadi ungkapan cocok atau tidak cocok, sesuai atau tidak sesuai. Dalam pengertian yang paling sederhana hal ini adalah sebuah penilaian atau kesan yang setidaknya ada dua ungkapan kontradiktif yang sering kita dengar dari para penikmat musik Bali. Ungkapan pertama mengatakan: "gendinge ento luwung pesan....jeg lemuh.....bun gendinge mapah biu (gending itu bagus sekali....enak...konturnya bagaikan pelepah pisang). Sedangkan ungkapan yang satu lagi mengatakan: "beh...dadi singkuh pesan gendinge ene...elung....jeg likad rasane " (wah gending ini kurang enak... .rasanya janggal sekali) (Rai, 2004:9).

Mengacu pada ungkapan kontradiktif di atas, ada hal mendasar yang perlu dicermati oleh seorang penata gending agar setiap karya yang dihasilkan mampu memenuhi setidaknya rasa "enak" pada si penikmat. Rasa "enak" itu diperluas lagi ketika penggunaan gending untuk suatu tujuan tertentu, apakah sudah sesuai, cocok atau tidak. Tulisan ini memang dimaksudkan untuk mengungkap tabir yang tersimpan dalam beberapa gending, mencermati unsur-unsur baik musikal maupun ekstra-musikal mencari analogi, melakukan komparasi, guna mendapatkan apa yang mempengaruhi perbedaan rasa musikal gending tersebut. Dari pengamatan sederhana penulis menduga sedikitnya ada tujuh rasa/nuansa yang dapat dijadikan titik tolak pengamatan dari penyajian sebuah karya karawitan Bali seperti: 1) rasa sedih, susah, galau, 2) marah, dengki, tegang, 3) gembira, senang, bahagia, 4) romantis, indah, ngulangunin, 5) kocak, lucu, 6) seram, takut, ngeri, men-cekam, dan 7) tenang, damai, khususk, agung,

Dengan meneliti semua unsur yang berperanan untuk mendukung terbentuknya rasa/suasana tersebut, diharapkan dapat ditemukan jawaban sementara tentang teori rasa dalam musik Bali walaupun sifatnya hanya sebagai pedoman pokok.

\section{KARAWITAN BALI}


Seniman karawitan Bali masa lampau sesungguhnya sudah sangat peka terhadap rasa musikal, hal itu kita warisi hingga sekarang dan kita cukup dibuat terpesona ketika mendengarkan gending-gending ciptaan mereka, rasa musikalnya enak dan cocok/sesuai dengan apa yang mereka ingin ungkapkan. Ketika hal ini ditanyakan kepada beberapa guru senior tradisional mereka menjawab dengan bermacam-macam. Ada yang menyebutkan hal itu disebabkan sang komposer masa lampau sudah sangat sepuh dan sangat peka terhadap rasa musikal, namun ada juga menyebutkan karena sang komposer masa lampau membuat lagu melewati eksplorasi yang mantap dan membutuhkan waktu yang cukup lama termasuk mengadakan semedi sebelum mencipta lagu (Wawancara dengan I Wayan Berata tanggal 28 Juli 2004 dirumahnya). Jawaban seperti ini tentu sifatnya sangat filosofis bahkan mungkin juga politis sehingga membuat kita selalu tanda tanya dan terus ingin menelusuri guna mendapatkan jawaban yang lebih mudah dipahami dari segi keilmuan.

Beberapa literarur telah ada yang menyinggung masalah rasa musikai seperti misalnya Lontar Prakempa dan Aji Gurnita, kedua lontar ini sesungguhnya telah menjelaskan teori rasa dalam karawitan Bali, walaupun untuk memahami secara mendalam masih sangat susah karena sifat literatur tersebut lebih mengedepankan aspek estetika filosofis. Di satu sisi dewasa ini kita sangat membutuhkan teori yang bisa memandu para seniman muda untuk memahami teori sekaligus mempraktekkannya.

Lontar Prakempa menyebutkan ada empat aspek utama dalam gamelan Bali yaitu tatwa (filsafat atau logika), susila (etika), lango (estetika), dan gegebug (teknik) (Bandem, 1986:1). Keempat unsur pokok sebagai isi dari lontar Prakempa ini pada dasarnya sebuah sumber berharga guna mencermati teori rasa musikal dalam karawitan Bait. Sebagai sebuah pedoman pokok keempat aspek utama ini masih perlu diteliti secara mendalam untuk bisa dijadikan landasan dalam menguraikan lebih eksplisit untuk menjadi sebuah keterangan yang mudah dicerna.

Lontar Aji Gurnita ada menyebutkan sebuah bab khsus yang diberi judul Tutur Catur Muni-Muni, yaitu empat gamelan sekawan yang semuanya dianggap bersumber pada gamelan Gambuh, sebuah gamelan yang konon penciptanya adalah para dewa dari langit (Ibid., p. 6). Gamelan Gambuh atau Pegambuhan oleh seniman Bali sering disebut-sebut sebagai "tambang emas" atau sumber inspirasi atau sumber acuan penciptaan gamelan dan repertoar gamelan lainnya $\mathrm{Hal}$ ini berarti dengan mengoreksi secara detail unsur-unsur musikal gamelan Gambuh akan ditemukan seperangkat cara atau aturan untuk menciptakan sebuah lagu yang baik. 
Penelitian yang sifatnya menerangkan lebih detail mengenai isi Lontar Prakempa dan Aji Gurnita sesungguhnya sudah dilakukan oleh seniman karawitan Bali dan banyak melahirkan teori-teori yang sangat bermanfaat bagi pembelajaran karawitan Bali. Almarhum I Gusti Putu Geria lewat analisisnya telah melahir-kan konsep Tri Angga, sebuah teori logika musikal dan bedah struktur karawitan Bali, yang pada dasarnya adalah konsep estetika dalam memahami struktur. Teori ini sampai sekarang selalu dijadikan pedoman bagi para komposer untuk membuat struktur gending menjadi harmonis serta memiliki kaedah-kaedah estetika.

I Made Bandem selain telah menterjemahkan dan membedah dengan cermat isi Lontar Prakempa dan Aji Gurnita, juga menelaah dan menguraikan lebih detail aspek teknik/gegebug kemudian menyusun sebuah artikel berjudul Ubit-Ubitan, Sebuah Teknik Permainan Gamelan Bali. Ubitubitan atau kotekan yang dianalisis oleh I Made Bandem berdasarkan informasi dua maestro karawitan Bali yaitu almarhum I Gusti Putu Geria dan almarhum I Nyoman Kaler. Lebih lanjut disebutkan bahwa ragam kotekan atau ubit-ubitan juga akan menentukan rasa musikal tertentu (Ibid., p. 15).

I Wayan Rai S dalam orasi ilmiahnya berjudul Unsur Musikal dan Ekstra Musikal dalam Penciptaan Gending-Gending Iringan Tari Bali juga telah memberikan panduan kepada kita untuk memahami karakterisasi karawitan sebagai iringan tari. Rai menyebutkan ada dua unsur penting yang dijadikan acuan oleh komposer dalam menciptakan iringan tari Bail yaitu unsur musikal dan unsur ekstra musikal (Rai, op. cit. p. 4). Penelitian yang dilaku-kan I Wayan Rai ini masih merupakan hasil analisis dan hipotesa awal untuk dijadikan acuan dalam mengadakan penyelidikan yang sifatnya lebih detail.

Colin McPhee dalam bukunya berjudul Music In Bali (1966) juga menjelaskan tentang adanya variasi dalam tetekep yang dapat melahirkan karakterisasi gending-gending Pegambuhan. McPhee menyebutkan tetekep selisir memiliki karakter halus (refined), tetekep tembung memiliki karakter keras (coarse), sedangkan tetekep sundaren memiliki karakter antara halus dan keras. Tetekep tebeng juga berkarakter halus tetapi biasanya digunakan secara khusus untuk mengiringi tokoh putri (princess), sedangkan tetekep baro untuk mengiringi tokoh pelayan dan pelawak dalam dramatari Gambuh (Phee, 1966:40). Namun demikian apa yang menyebabkan variasi tetekep itu dapat menentukan perbedaan rasa belum dijelaskan secara detail McPhee hanya menjeiaskan kenyataan yang biasa dipergunakan kemudian dideskripsi seperti tersebut di atas.

\section{RASA DALAM KARAWITAN BALI}


Untuk menerangkan masalah rasa yang dijadikan topik sentral dalam tulisan ini merupakan sesuatu yang sangat subyektif sifatnya karena begitu luas pengertian dan pemahaman manusia tentang apa yang disebut rasa. Dalam membuat deskripsi akan digunakan beberapa definisi yang pernah diungkapkan oleh beberapa ahli kemudian disesuaikan dengan kondisi yang terjadi pada objek penelitian. Memang harus diakui kenyataan bahwa merasakan sesuatu akan terjadi begitu saja, namun menjelaskan apa yang disebut rasa itu sendiri akan semakin pusing kita dibuatnya.

Salah satu pepatah tersohor dari Kitab Natyasastra India berbunyi: "Rasa dilahirkan dari manunggalnya situasi yang ditampilkan bersama dengan reaksi-reaksi serta keadaan batin para pelaku yang terus menerus berubah". Pengertian rasa seperti tersebut di atas tidak tepat sama dengan "rasa' dalam bahasa Indo-nesia yang biasanya disebut "perasaan" atau emosi. Pengertian emosi dalam Kitab Natyasastra disebut bhava yang jumlahnya ada delapan yaitu: emosi senang, kegembiraan, kesedihan, kemurkaan, kebulatan tekad, ketakutan, kebencian, dan emosi kagum. Kedelapan emosi ini tidak selalu tampak dalam keadaan murni, akan tetapi sering tercampur, saling berhubungan dan bersifat sementara. Kedelapan jenis bhava ini digunakan sebagai patokan memerankan tokoh-tokoh dalam seni drama India (Hartoko, 1984:68).

\section{Rasa Musikal}

Penampilan sebuah karya musik sarat dengan penggambaran, atau pengungkapan emosional yang diciptakan sang komposer, dimainkan oleh pemusik kemudian ekspresi emosional tersebut ditransfer dengan bahasa musik kepada penikmat. Dalam hal inilah adanya rasa yang dinikmati sangat menentukan keberhasilan sebuah karya musik.

Tersebut di atas adalah delapan perasaan atau bhava yang dipergunakan sebagai pedoman seni drama di India. Berdasarkan hipotesa penulis, dalam karawitan Bali juga dapat diamati sedikit-nya tujuh rasa yang sering disebut rasa musikal. Rasa musikal dapat didefinisikan sebagai ungkapan atau ekspresi manusia yang dapat dinikmati melaui media auditif. Indra penikmat secara pokok adalah telinga, namun ketika penikmatan berlanjut lebih mendalam, maka banyak indra yang pada akhirnya berperan untuk dapat menikmati rasa auditif tersebut.

Sebagai kenikmatan estetis musik dapat memberikan rasa nikmat, rasa segar, rasa damai terhadap manusia, dan bila penikmat-an itu mendalam manusia cendrung menjadikan ia sebagai sarana komunikasi internal daiam dirinya, sebagai terapi berbagai faktor psikis manusia. Dalam ilmu psikologi diyakini musik sebagai salah satu alat terapi yang berfungsi untuk meredam ketegangan saraf agar kembali normal. Selain itu sebagai kenikmatan estetis 
musik juga dapat menghilangkan kebosanan, rasa sumpek, capek, dan kekalutan pikiran.

Sebagai sarana hiburan, musik merupakan media rekreasi yang dinikmati secara santai dan simpel. Mendengarkan musik akan dapat mengarahkan pikiran manusia sementara waktu terhadap hal-hal yang menghibur diri sehingga permasalahan-permasalahan dan rutinitas seharihari menjadi terobati. Munculnya berbagai jenis rekaman baik secara audio maupun audio-visual menjadikan musik sebagai salah satu sarana hiburan yang sangat digemari manusia dewasa ini.

Musik dengan daya tariknya dapat menjadikan fisik manusia untuk meresponnya. Manusia akan merespon dengan berjingkrak-jingkrak, menghentakkan kaki, bertepuk tangan, ketika menikmati sebuah musik yang bernuansakan keceriaan dan kegembiraan. Begitu juga manusia akan merasakan ketakutan, gugup, atau was- was ketika dihadapkan pada musik yang bernuansa magis, seram dan itu direspon dengan perubahan fisik dan psikisnya. Tidak jarang pula ketika nuansa musik begitu menyengat batin manusia dengan nuansa sedih dan haru seketika itu manusia akan menangis ketika menikmati musik tersebut. Hal inilah salah satu kehebatan dari nuansa atau rasa musikal yang dapat membuat fisik manusia responsif terhadapnya.

\section{Rasa Romantis}

Dalam berbagai bentuk seni pertunjukan seperti Tari Pelegongan atau Legong Keraton, Dramatari, Sendratari, maupun tari-tarian lepas lainnya sering kita jumpai adegan roman yang biasanya disebut aras-arasan atau ipuk-ipukan. Bagian ini tentu menuntut iringan yang bernuansa sangat romantis untuk dapat memperkuat suasana dan memberi aksentuasi sehingga dapat mentransformasikan bagaimana rasa romantis tersebut tercapai kepada sang penikmat. Menurut pengamatan penulis. lagu-lagu iringan maupun non iringan yang menyajikan nuansa percintaan menuntut pengolahan unsur musikal yang sangat kreatif dan variatif sehingga memiliki permasalahan yang paling kompleks diantara lagu-lagu sentimentil lainnya.

Para komposer dari berbagai generasi mulai era tahun 1940-an hingga sekarang seperti Wayan Berata, Nyoman Astita, Nyoman Windha, Made Subandi, Wayan Darya, Ketut Garwa dan lain se-bagainya tampaknya memiliki problem dan pandangan yang sama dalam membuat lagu-lagu yang bernuansa romantis. Selain pe-ngolahan unsur musikal instrumental secara maksimal, mereka juga selalu melibatkan unsur musik vokal untuk menambah mantapnya suasana yang diinginkan.

Ketut Garwa seorang komponis muda yang cukup ber-pengalaman dalam menata lagu-lagu iringan sendratari maupun dramatari mengatakan bahwa bila menata lagu-lagu yang bernuansa romantis dibutuhkan perenungan dan penghayatan yang mendalam sehingga lagu yang diwujudkan betul-betul dapat mewakili perasaan penata yang berbunga- 
bunga (Wawancara dengan Komponis Ketut Garwa pada tanggal 2 September 2004).

Contoh lagu yang bernuansa romantis:

Lagu “Aras-Arasan Jayaprana Layonsari”

Karya: Wayan Berata

$$
\begin{aligned}
& \text { Kawitan : - - - E O O E O - - - O I I A U } \\
& -E-I-O-E-E-E-A I O \\
& -\mathrm{O}-\mathrm{O}-\mathrm{I} \mathrm{A} \mathrm{U}-\mathrm{O} \mathrm{O}-\mathrm{O}- \\
& O-O E-U-A
\end{aligned}
$$

Pengawak :

$$
\begin{aligned}
& -----A-U E A-U E O \\
& \text { - - - - - - }-\mathrm{EO} \mathrm{O}-\mathrm{U}-\mathrm{A} \\
& \text { - - - - - - - U - E - A - U } \\
& \text { - - E - O - E - O - I - A I O } \\
& -\quad-\quad-\quad-\quad-A-I \text { A I O E } \\
& \text { - - - - - - - U - A - U - E } \\
& \text { - }- \text { A O A U - E - A U E } \\
& \text { - }-\mathrm{O}-\mathrm{EUEU}-{ }_{-}-{ }_{-}-{ }_{-} \mathrm{A} \\
& \text { - A O E - U - A }
\end{aligned}
$$

Pengecet :

$$
\begin{aligned}
& \text { - I - A - U - E - U A I A U E U } \\
& \text { - I - A - U - E - U A U A U E O } \\
& \text { - O - O E O I A - A - A I A U E } \\
& -E-U-A-I-E-O-I-A \\
& -\mathrm{E}-\mathrm{O}-\mathrm{I}-\mathrm{A}-\mathrm{E}-\mathrm{O}-\mathrm{I}-\mathrm{A} \\
& \text { - U E U A I A U }
\end{aligned}
$$

\section{Rasa Senang}

Lagu-lagu yang memang murni untuk menggugah rasa senang si penikmatnya lebih banyak disajikan sebagai musik instrumentalia atau komposisi murni seperti yang terjadi pada lagu-lagu kekebyaran kreasi baru dan pada umumnya bagian ini ditempatkan pada bagian akhir atau pengecet. Pengolahan-pengolahan unsur musikal yang mendominasi untuk 
memunculkan rasa senang dilakukan dengan olahan ritme, melodi ditambah dengan ornamentasi yang sangat variatif.

Wayan Berata, seorang maestro karawitan Bali yang telah banyak berkiprah dalam penciptaan komposisi kekebayaran mengatakan bahwa, pengolahan unsur-unsur musikal untuk dapat menampilkan lagu bernuansa senang adalah sangat bervariasi. Pengolahan nada-nada untuk membuat jalinan melodi, pengolahan tempo sedang (march) namun lebih lincah dan dinamis, teknik permainan yang bervariasi, dan ornamentasi yang sangat diperhitungkan, dinamika yang dinamis, merupakan ciri-ciri lagu yang dapat menggugah rasa senang kepada sipenikmatnya (Wawancara dengan Bapak Wayan Berata pada tanggal 5 September 2004 di rumahnya).

Contoh dari lagu yang memiliki nuansa untuk dapat menggugah rasa senang kepada si penikmat:

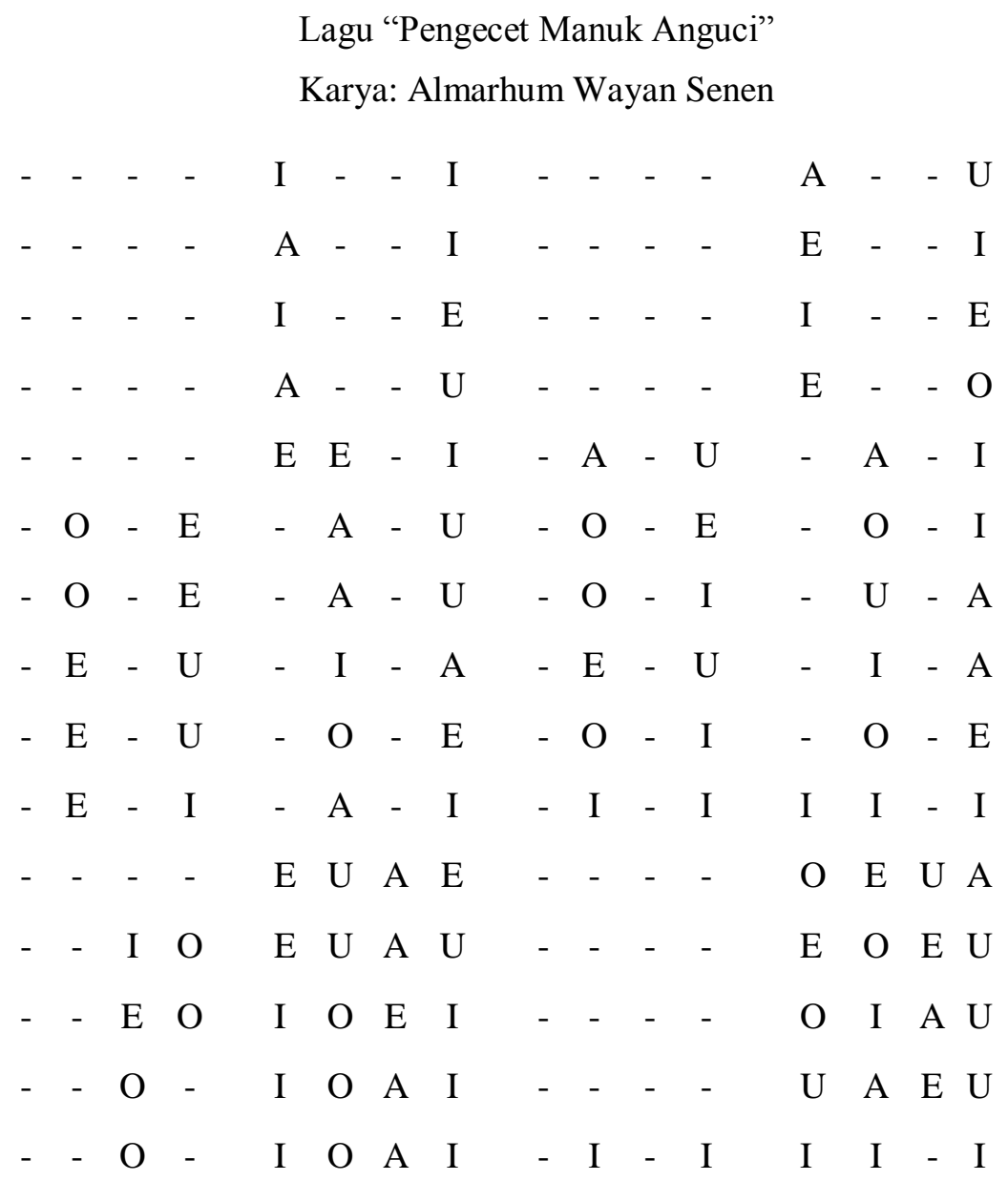




\section{Rasa Sedih}

Secara konvensional kita telah banyak divarisi gending-gending yang bernuansa sedih, terutama yang digunakan untuk iringan seni pertunjukan. Gending-gending seperti ini sering disebut dengan legodbhawan seperti banyak dijumpai pada iringan dramatari, sendratari, drama gong dan lain sebagainya.

Dalam pengolahan unsur-unsur musikai lagu yang bernuansa sedih pada umumnya memiliki melodi mengalun, temponya lambat,. dinamikanya sayup-sayup, teknik sederhana dan tidak banyak variasi. Dari sisi melodi, lagu-lagu bernuansa sedih lebih didorninasi oleh nada I (ding) dan U (dung).

Contoh lagu bernuansa sedih:

$$
\begin{aligned}
& \text { Lagu "Sedih Sita" pada Sendratari Ramayana } \\
& \text { Karya: Wayan Berata } \\
& \hline \\
& \hline
\end{aligned}
$$

\section{Rasa Tenang}

Lagu-lagu yang bernuansa tenang, damai, dan hidmat yang dimaksudkan disini adalah lagu-lagu yang biasanya digunakan sebagai iringan dalam rangkaian upacara keagamaan (Agama Hindu Bali) terutama dalam upacara Dewa Yadnya. Lagu-lagu seperti ini biasanya terkesan magis seolah-olah perasaan pendengaranya ingin dibawa ke alam atas (alam maya) dimana para dewa bersemayam.

Dalam pengolahan unsur-unsur musikal biasanya lagu-lagu ini memiliki melodi yang cukup simpel atau sederhana dengan motif yang disebut leluwangan. Teknik permainan terutama instrumen-instrumen melodis berbilah lebih banyak sistem keklenyongan yaitu dengan memainkan nada-nada yang paling pokok. Selain keklenyongan biasanya juga digunakan teknik noltol yaitu memukui semua nada yang ada diantara nada-nada pokok. Dinamikanya ajeg atau datar dengan tempo sedang dan ritmenya agak stakato. 
Contoh lagu yang bernuansa tenang dan damai:

Gending Rejang Dewa

\begin{tabular}{|c|c|c|c|c|c|c|c|c|c|c|c|}
\hline $\mathrm{E}$ & - & $\mathrm{U}$ & - & $\mathrm{E}$ & & $\mathrm{O}$ & - & & & & \\
\hline $\mathrm{U}$ & - & $\mathrm{A}$ & 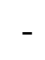 & $\mathrm{U}$ & 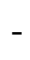 & $\mathrm{E}$ & 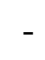 & A & & & $\mathrm{U}$ \\
\hline $\mathrm{A}$ & - & I & - & $\mathrm{O}$ & 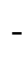 & $\mathrm{E}$ & - & & & & $\mathrm{A}$ \\
\hline $\mathrm{O}$ & I & $\mathrm{A}$ & - & I & 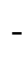 & $\mathrm{O}$ & 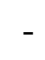 & & & & $\mathrm{E}$ \\
\hline $\mathrm{I}$ & - & $\mathrm{O}$ & - & I & 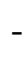 & A & - & & & & I \\
\hline- & - & $\mathrm{E}$ & 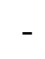 & $\mathrm{O}$ & 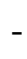 & I & 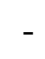 & & & & $\mathrm{O}$ \\
\hline- & - & $\mathrm{O}$ & - & A & & I & 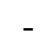 & & & & $\mathrm{O}$ \\
\hline $\mathrm{U}$ & E & $\mathrm{O}$ & - & $\mathrm{E}$ & & $\mathrm{U}$ & - & 0 & & & I \\
\hline
\end{tabular}

\section{Rasa Lucu/Kocak}

Lagu-lagu yang bernuansa lucu/kocak biasanya digunakan untuk mengiringi tari-tarian yang bertemakan kerakyatan atau adegan rakyat dalam sendratari maupun dramatari. Gerak-gerak lucu yang ditampilkan sesungguhnya untuk menimbulkan rasa senang yang sifatnya menghibur para penonton sehingga seolah-olah rasa lucu identik dengan rasa senang.

Pengolahan unsur musikal sangat berbeda antara lagu yang bernuansa lucu dengan lagu yang bernuansa senang. Pada umumnya melodi yang bernuansa lucu dibuat stakato atau putus-putus dan lebih banyak menggunakan nada-nada tinggi dengan karakter lincah. Ritmenya bervariasi, ritmis, penuh dengan aksentuasi, temponya kebanyakan sedang terkadang cepat, nuansa musikalnya cukup dinamis dan leknik yang digunakan sangat variatif.

Contoh dari lagu yang memiliki nuansa untuk dapat menggugah rasa lucu/kocak:

Lagu Rakyat pada Sendratari Satrya Taman Bali

Karya: Nyoman Windha
E A A E
E A A E
O U U O
O U U O
E A A E
E A A E
O U U O
$\mathrm{U} \quad \mathrm{U} \quad \mathrm{O} \mathrm{U}$
- U U -
O E U E
$U A-U$
E $\quad$ O $\quad$ I $\quad$ O 


\begin{tabular}{|c|c|c|c|c|c|c|c|c|c|c|c|c|}
\hline I & A & & I & OI & -I & $\mathrm{O}$ & $A$ & & $\mathrm{U}$ & OI & A & $\mathrm{UE}$ \\
\hline E & $\mathrm{E}$ & - & - & - & - & $\mathrm{E}$ & F & $\mathrm{E}$ & & $\mathrm{U}$ & I & A L \\
\hline OI A & A & A & A & A & IO & $\mathrm{E}$ & - & - & A & A & - & \\
\hline A & $\mathrm{U}$ & A & $\mathrm{E}$ & $\mathrm{U}$ & A & - & $\mathrm{U}$ & E & $\mathrm{U}$ & $\mathrm{O}$ & E & $\mathrm{U}$ \\
\hline- & - & - & $\mathrm{Al}$ & $\mathrm{O}$ & I & $\mathrm{O}$ & - & $\mathrm{U}$ & A & $\mathrm{E}$ & $\mathrm{U}$ & A \\
\hline $\mathrm{U}$ - & $\mathrm{E}$ & $\mathrm{U}$ & $\mathrm{O}$ & E & $\mathrm{U}$ & $\mathrm{E}$ & $\mathrm{AA}$ & A & A & - & A & A \\
\hline & I & $t$ & A & 0 & $\mathrm{E}$ & 0 & & & & & & \\
\hline
\end{tabular}

\section{Rasa Marah}

Lagu-lagu yang bernuansa tegang, marah, dan dengki secara tradisi banyak kita jumpai dalam iringan Pelegongan dengan motinagu batel dan bapang. Demikian juga dalam lagu-lagu kekebyaran banyak menggunakan motif-motif lagu seperti batel, bapang, gilak, dan kale. Lagu-lagu tersebut di atas biasanya digunakan pada adegan pesiat atau perang dalam dramatari maupun sendratari yang menggunakan iringan gamelan Kebyar.

Pengolahan unsur musikal pada motif-motif lagu seperti gilak, kale, batel, dan bapang seperti tersebut di atas, sesungguhnya sangat sederhana, Melodinya pendek-pendek dengan satu atau dua hitungan/ketukan dalam satu gong, dan yang terpanjang biasanya bapang bisa mencapai delapan hitungan dalam satu gong. Motif batel bahkan dibuat tanpa melodi, dengan tempo cepat dengan diberi aksentuasi-aksentuasi tertentu sebagai penekanan bagian-bagian lagu, sedangkan teknik yang digunakan adalah noltol.

Berikut ini contoh lagu bernuansa marah:

Gending Batel:

$$
-+-(.)
$$

Gending Bapang:

$$
\begin{aligned}
& \mathrm{A}-\mathrm{O}-\mathrm{A} \text { - } \mathrm{O} \\
& \text { A U O U A U O U } \\
& \text { A I O E A I O E }
\end{aligned}
$$

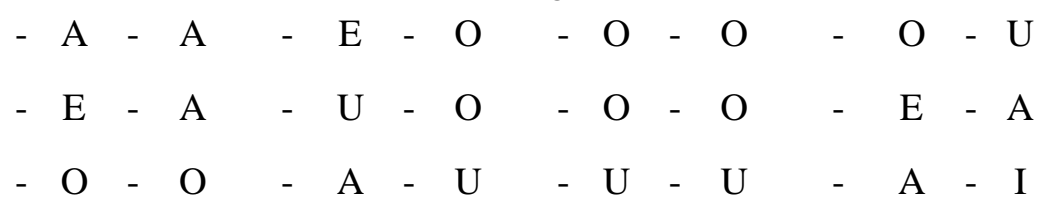


Gending Gilak Perang (Karakter Keras)

\begin{tabular}{|c|c|c|c|c|c|c|c|c|c|c|}
\hline A & I & $\mathrm{A}$ & I & & $\mathrm{A}$ & I & & A & & \\
\hline A & I & $\mathrm{A}$ & I & - & $\mathrm{A}$ & I & - & A & & \\
\hline A & - & $\mathrm{U}$ & - & $\mathrm{E}$ & - & $\mathrm{U}$ & . & 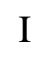 & & \\
\hline$\ldots$ & $\mathrm{U}$ & $\mathrm{E}$ & $\mathrm{O}$ & $\mathrm{E}$ & $\mathrm{U}$ & - & 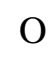 & 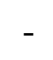 & & \\
\hline I & $\mathrm{O}$ & I & $\mathrm{O}$ & & $\mathrm{E}$ & I & & $\mathrm{U}$ & I & $\mathrm{O}$ \\
\hline
\end{tabular}

\section{Rasa Takut}

Lagu-lagu yang dapat membuat perasaan merinding atau membuat berdiri bulu roma dalam karawitan Bali adalah lagu-lagu jenis tunjang. Lagu jenis ini dipergunakan sebagai iringan seni pertunjukan baik dalam bentuk sendratari, dramatari maupun jenis tari-tarian lainnya. Dramatari Calonarang merupakan jenis seni pertunjukan konvensional yang bertemakan ilmu hitam sehingga dramatari ini didorainasi dengan iringan yang bernuansakan seram, magis sehingga dapat membuat rasa takut kepada para penonton.

Dari sisi pengamatan musikologis, pengolahan unsur musikal pada lagu-lagu jenis tunjang adalah: 1) Melodinya cukup lincah namun dipandu dengan dinamika yang sayup-sayup dan mengalun. 2) Tempo sedang dengan ritme yang ajeg hampir statis.3) Teknik permainan disebut noltol yaitu memukul semua nada secara merata baik nada pokok maupun titi nadanya, dan 4) Sebagai finalis melodi pada lagu-lagu tunjang biasanya dipilih nada $\mathrm{U}$ (dung) dan $\mathrm{O}$ (dong), karena nada-nada ini terkesan berat dan angker sehingga sangat mendukung gending-gending tunjang untuk mewujudkan suasana angker yang menakutkan.

Contoh gending tunjung:

Gending Tunjung Sisya Ngerah

$$
\begin{aligned}
& \text { - - U - - }- \text { U E A U E - U - A } \\
& \text { - }-\mathrm{A}-\mathrm{I}-\mathrm{O}-\mathrm{O}-\mathrm{E} \text { U EOEU } \\
& -{ }_{-} \mathrm{U}-{ }_{-} \mathrm{U} \text { E A U E - U - A } \\
& \text { - - A - I - O - O - E U E OE U } \\
& \text { - - U - - - U E O E U - E UEO } \\
& \text { - - O - E - U - U - E U E OE U } \\
& \text { - }-\mathrm{U}-{ }_{-} \text {- U E O E U - E UE O }
\end{aligned}
$$




\begin{tabular}{|c|c|c|c|c|c|c|c|c|c|c|c|c|}
\hline- & - & $\mathrm{O}$ & & $\mathrm{E}$ & - & $\mathrm{U}$ & $\mathrm{U}$ & & $\mathrm{E}$ & $\mathrm{U}$ & & $\mathrm{DE}$ \\
\hline- & - & $\mathrm{U}$ & - & - & - & $\mathrm{U}$ & $\mathrm{EO}$ & E & $\mathrm{U}$ & - & & UE O \\
\hline $\mathrm{O}$ & I & A & $\mathrm{O}$ & I & A & I & $\mathrm{OE}$ & $\mathrm{O}$ & $\mathrm{E}$ & - & & \\
\hline $\mathrm{U}$ & - & $\mathrm{E}$ & - & $\mathrm{O}$ & - & $\mathrm{E}$ & $\mathrm{UA}$ & $\mathrm{U}$ & $\mathrm{A}$ & - & & \\
\hline A & & $\mathrm{U}$ & 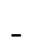 & $\mathrm{E}$ & - & $\mathrm{O}$ & E U & $\mathrm{E}$ & $\mathrm{U}$ & - & & \\
\hline
\end{tabular}

\section{SIMPULAN}

Munculnya tujuh rasa musikal yang dapat diungkapkan dengan bahasa musik lewat instrumen-instrumen pendukung gamelan Gong Kebyar pada dasarnya sangat tergantung dari kemampuan sang komposer untuk meramu bahan-bahan mentah yang telah disediakan oleh perangkat gamelan Gong Kebyar. Dalam mengolah bahan-bahan tersebut hingga dapat menampilkan berbagai jenis rasa musikal seperti rasa romantis, rasa senang, rasa sedih, rasa tenang, rasa lucu, rasa marah, dan rasa takut diharapkan terjadi transfer of feeling atau pemindahan rasa dari sang komposer sehingga penikmat juga dapat merasakan apa yang diinginkan sang komposer.

Untuk menyebutkan secara difinisi hal atau faktor apa yang menyebabkan munculnya perbedaan jenis rasa musikal dalam gamelan Gong Kebyar tersebut dapat diamati dari dua paradigma pokok yaitu unsur ekstra musikal dan unsur musikal. Unsur ekstra musikal terkaitan dengan masalah filosofi, fungsi dan penggunaan yang mendasari munculnya berbagai jenis rasa musikal dalam gamelan Bali. Dua literatur pokok yaitu Lontar Prakempa dan Aji Gurnita merupakan sebuah sumber filosofis utama digunakan untuk menjelaskan unsur-unsur ekstra musikal yang mempengaruhi perwatakan rasa musikal gamelan Bali.

Faktor pengolahan musikal merupakan hal yang paling menentukan dalam pengungkapan berbagai jenis rasa dalam gamelan Bali termasuk gamelan Gong Kebyar. Setidaknya ditemukan tujuh unsur musikal yang mesti mendapat perhatian serius guna mengungkapkan rasa musikal yang sistem pelarasan gamelan, ukuran lagu/gending, pengolahan nada dan melodi, permainan tempo, penentuan ornamentasi atau pepayasan, daya tarik menarik nada (power attraction among tones), dan logika musikal. Ketujuh unsur ini dijadikan panduan atau dijadikan "pisau" untuk mengolah unsurunsur musik tersebut sehingga mampu diungkap berbagai jenis rasa musikal.

\section{DAFTAR RUJUKAN}

Arya Sugiartha, 1 Gede. 1996. Gamelan Pegamhuhan: Pengaruhnya Terhadap Gamelan Golongan Madia dan Barn Dalam Karawitan Bali, Tesis S2 pada Universitas Gadjah Mada Yogyakarta. 
Bandem, I Made. 1986. Prakempa Sebuah Lontar Gamelan Bali, Denpasar: Sekolah Tinggi Seni Indonesia.

Bandem, I Made, "Ubit-Ubitan Sebuah Tekntk Permainan Gamelan Bali", Denpasar: Daftar Isian Kegiatan STSI Denpasar Nomor 080/23/S99I.

Hartoko, Dick. 1984. Manusia dan Seni, Yogyakarta: Penerbit Kanisius.

Mack, Dieter. 1994. Ihnu Melodi, Yogyakarta: Pusat Musik Liturgi.

Phee, Colin Mc. 1964. Music In Bali: A Study in Form and Intrumental Organization in Balinese Orchestral Music, New Haven and London: Yale University Press.

Rai S, I Wayan (dkk). 1999. "Keragaman Laras (Tuning System) Gameian Gong Kebyar di Bali”. Laporan Penelitian Hibah Bersaing, Direktorat Jenderal pendidikan Tinggi Depdiknas.

Rai S, I Wayan. 2004. "Unsur Musikal dan Ekstra-Musikal Dalam Penciptaart Gending Iringan Tari Bali”, Orasi 1lmiah daJam rangka Pengukuhan Guru Besar Bidang Etnomusikologi pada Institut Seni Indonesia Denpasar, Tanggal 28 Januari 2004.

Soedarso Sp. 1990. Tinjauan Seni Sebuah Pengantar untuk Apresiasi Seni, Yogyakarta: Saku Dayar Sana Yogyakarta.

\section{NARA SUMBER}

1. Wayan Berata
Tempat/Tahun Lahir
Denpasar, 1942
Pekerjaan
: Komposer, kreografer, guru gamelan dan wirausaha.

Alamat : Jn. Pucuk 11 Denpasar.

2. Ketut Garwa

Tempat/Tahun Lahir $\quad$ : Bamgli, 1969.

Pekerjaan

: Dosen ISI Denpasar.

Alamat

: Desa Bebalang, Bangli. 